

\title{
The concept of crime detection in Russian law
}

\author{
DOI: https://doi.org/10.46398/cuestpol.3970.35
}

\author{
Ivan Alexandrovich Zavyalov * \\ Taulan Osmanovich Boziev ** \\ Nikolay Nikolaevich Bukharov *** \\ Alexandr Vladimirovich Shakhmatov **** \\ Nikolay Kazimirovich Pcholovsky *****
}

\begin{abstract}
The article examines the problem of determining the essence of the concept of "crime detection" in Russian law. For this purpose, the method of literature review was used and during the study the authors analyzed the normative legal acts of the Russian Federation, such as: the constitution of the Russian Federation, the Criminal Code of the Federation, the Code of Criminal Procedure and the Federal Law «on Operational Search Activity», the Federal Law "on police forces", interdepartmental and departmental normative legal acts of the Ministry of Internal Affairs of Russia, among others, to determine the precise moment of detection of the crime phenomenon. Moreover, the article proposes to clarify the definition of the term "crime detection". It is concluded that it is advisable to distinguish the concepts of «crime detection» and other related concepts
\end{abstract} in practice and theory to avoid confusion.

Keywords: operational search activity; criminalistics; criminal law; criminal procedure; internal affairs bodies.

* Moscow University of the Ministry of Internal Affairs of the Russian Federation named by V.YA. Kikot, Moscow, Russia. ORCID ID: https://orcid.org/oooo-0002-8877-9666. Email: zavyalov.i.a@bk.ru

** State Institute of Economics, Finance, Law and Technology, Gatchina, Russia; St. Petersburg State University of the Interior Ministry of Russia, St. Petersburg, Russia. ORCID ID: https://orcid. org/oooo-ooo3-4782-9118. Email: Taulan.Boziev@yandex.ru

*** St. Petersburg University of the Ministry of Internal Affairs of Russia, St. Petersburg, Russia. ORCID ID: https://orcid.org/oooo-0002-8138-205X. Email: bukharov.n.n@mail.ru

**** St. Petersburg University of the Ministry of Internal Affairs of Russia, St. Petersburg, Russia; St. Petersburg Academy of the Investigative Committee of the Russian Federation, St. Petersburg, Russia. ORCID ID: https://orcid.org/oooo-0003-4859-172X. Email: shakhmatov.a.v@mail.ru

**** St. Petersburg University of the Ministry of Internal Affairs of Russia, St. Petersburg, Russia. ORCID ID: https://orcid.org/oooo-0o01-7506-5448. Email: pcholovsky.n.k@mail.ru

Recibido el 06/07/2021 Aceptado el 28/08/2021 


\title{
El concepto de detección de delitos en la legislación rusa
}

\begin{abstract}
Resumen
El artículo examina el problema de determinar la esencia del concepto de "detección de delitos" en la legislación rusa. Para ello se utilizaron el método de revisión de la literatura y durante el estudio los autores analizaron los actos jurídicos normativos de la Federación de Rusia, como: la constitución de la Federación de Rusia, el Código penal de la Federación, el Código de Procedimiento Penal y la Ley Federal "sobre la Actividad de Búsqueda Operativa", la Ley Federal "sobre los cuerpos policiales", actos jurídicos normativos interdepartamentales y departamentales del Ministerio del Interior de Rusia, entre otros, para determinar el momento preciso de la detección del fenómeno delito. Por lo demás, en el artículo se propone clarificar la definición del término "detección de delitos". Se concluye que es aconsejable distinguir los conceptos de "detección de delitos" y otros conceptos afines en la práctica y en la teoría para evitar confusiones.
\end{abstract}

Palabras Clave:_actividad de búsqueda operativa; criminalística; derecho penal; procedimiento criminal; órganos de asuntos internos.

\section{Introduction}

In the practice of operational divisions of the internal affairs bodies of the Russian Federation, the concept of "crime detection" is one of the key ones (Thi Lan Hong et al., 2020). It is inextricably linked to the correct definition of criteria for assigning crimes to the categories of solved and unsolved, maintaining statistical reporting of the detection of crimes for a certain period, solving problems when comparing the results of the activities of various internal affairs agencies, their services, and divisions, as well as individual operational employees (Ivanov et al., 2020a; 2020b; Anyushina et al., 2021).

Understanding the essence of the term "crime detection" is extremely important in the scientific aspect. Understanding the essence of "operational investigative activity", determining the relationship between the concepts of "crime detection" and "investigation", distinguishing "crime detection" from "searching" etc. in turn, these concepts are the basis for the development of general theories of operational investigative activity and criminology, as well as private methods for identifying, preventing, suppressing, and disclosing certain types of crimes.

The theories of operational investigative activity, criminalistics, criminal procedure, and criminology contain numerous points of view about the concept of "crime detection", which are very different in their content and often exclude each other. 
Ivan Alexandrovich Zavyalov, Taulan Osmanovich Boziev, Nikolay Nikolaevich Bukharov, Alexandr Vladimirovich Shakhmatov y Nikolay Kazimirovich Pcholovsky

The concept of crime detection in Russian law

In our opinion, the lack of unity in views here is due to the complexity of the problem and the different approaches of individual authors to its solution, with differences in criteria and logical grounds for formulating definitions.

The subject of discussion is usually:

- essence of crime detection as a social phenomenon.

- the scope of this concept.

- the moment when the crime can be considered solved.

- correlation of crime detection with criminal prosecution of a person (Pushkarev et al., 2019).

All these issues are closely related to each other and depend on each other.

\section{The analysis of normative acts}

In our opinion, it is advisable to start considering the essence of the concept of "crime detection" by analyzing the normative legal acts of the Russian Federation. The Constitution of the Russian Federation (1993) in the Articles 20, 47, 48, 49, 50, 52, 63, 93, 98, 125 contains the word "crime", but the concept of "crime detection" in the Constitution is missing.

Federal Law No. 144-FZ "on Operational Search Activity” (August 12, 1995) in Article 2, defines the tasks and distinguishes: the identification, prevention, suppression, and detection of crimes, as well as the identification and identification of persons who are preparing, committing, or have committed.

At the same time, the meaning of the term "crime detection" in this normative legal act is absent. The Federal Law No. 3-FZ "on the Police" (2011), in Article 2, which sets out the main areas of police activity, declares one of them: identification and of crime, investigation of criminal cases without revealing the content of this word.

The Criminal Procedure Code of the Russian Federation 174-FZ (December 18, 2001) in Article 5, which lists the main concepts used in the Code, does not contain the term "detection of crimes". However, hereinafter referred to the Code, the concept of "crime detection" still occurs. In Article 317.1 Part 2, 317.5 Part 1, Item 1.2, 317.6, Part 2, Item 1, 317.7, Part 4, Item 1.2 of the Criminal Procedure Code of the Russian Federation, where we are talking about a special procedure for making a court decision at the conclusion of the pre-trial agreement on cooperation. This concept is present, but also is not revealed its essence. 
The Criminal Code of the Russian Federation No. 63-FZ (June 13, 1996) establishes the concept of "crime" in article 14, but does not tell us about its detection, does not explain what "crime detection" is. In the text of the criminal Law, we meet this concept, in particular, in Item "i", Part 1 of Article 61 "Circumstances mitigating punishment", Part 1 of Article 64 "Appointment of more soft punishment, than it is provided for this crime", Part 1 of Article 75 "Exemption from criminal liability in connection with active repentance". In the notes to Articles 110.2, 127.1, 178, 184, 200.5, 204, 204.1, 204.2, 205.3, 210, 212, 228, 228.3, 291, 291.1, 291.2, 322.2, 322.3 of the criminal Code the term "crime detection" exists and it is mostly about the active contribution to solving the crime by the person who committed the crime for which there is a in one of the listed articles of the special part of the criminal Code. However, the essence of the concept in question is not disclosed.

Having studied the texts of the listed normative legal acts, we have not found a definition of the concept of "crime detection" anywhere. However, clarification of this concept, as we noted earlier is extremely important for the theory and practice of operational and investigative activities.

There is the Interdepartmental order "on Unified Accounting of Crimes" (Interdepartmental order No. 39/1070/1021/253/780/353/399, 2005). The order regulates the current system of registration and accounting of the crimes in the police, but also does not contain the concept of "detected crime", but Paragraph 2.11 of this order gives the concept of an "unsolved crime":

"Unsolved crime" is a crime, the criminal proceedings of which have been suspended under Paragraphs 1, 2 and 3 of Part 1 of Article 208 of the Criminal Procedure Code of the Russian Federation".

In Section IV, "Registration of Persons Who Committed Crimes" of the same Order, in Paragraph 41, the reasons for registering the person who committed the crime are listed. These reasons are:

Indictment (act):

- a conviction in a private prosecution case that has entered into legal force.

- a decision to refuse to institute criminal proceedings (on nonrehabilitating grounds).

- decision to terminate a criminal case or criminal prosecution (on non-rehabilitative grounds).

The Order of the Ministry of internal Affairs of Russia No. 356 "About the Position statement about Appointment and Payment of Police Remuneration for Assistance in Solving Crimes and Apprehending 
Ivan Alexandrovich Zavyalov, Taulan Osmanovich Boziev, Nikolay Nikolaevich Bukharov, Alexandr Vladimirovich Shakhmatov y Nikolay Kazimirovich Pcholovsky

602

The concept of crime detection in Russian law

Offenders" (June 6, 2018) in Article 11, establishes that "the remuneration is paid to the citizen in case of a citizen initiative presenting them reliable information during the placement of ads on the official website of the Ministry of internal Affairs of Russia in the network "Internet", which led to the detection of crimes and the detention of those who committed them".

Article 12 stipulates that a decision on payment of remuneration is made after the arrest of persons for whom a reward has been declared, as well as after the indictment of persons whose involvement in crimes has been established by the information provided, or after one of the following decisions has been made in a criminal case against the named persons:

1. On the termination of criminal case and (or) criminal prosecution on the basis provided for in Paragraphs 3 and 4 of Part one of Article 24 of the Criminal Procedure Code of the Russian Federation.

2. On the termination of a criminal case and (or) criminal prosecution on the basis provided for in Paragraph 3 of Part one of Article 27 of the Criminal Procedure Code of the Russian Federation".

Thus, based on the analysis of interdepartmental and departmental normative legal acts, we must assume that in the practice of law enforcement agencies, the crime will be considered detected when the authorized official takes into account the person who committed it in the relevant information Center of the Ministry of internal Affairs, making the necessary card form No. 2 (annex to the said Interdepartmental Order) for one of the listed reasons.

The dictionary of the Russian Language interprets the word "detection" as "discover, make known, explain (something secret, unknown, etc.)" (Ozhegov, 1981).

\section{Opinion of scientists}

Understanding the essence of the concept of "crime detection" is impossible without considering the opinions of scientists in the field of law.

It should be noted that the question of when the crime can be considered detected is debatable. Some authors consider that the detection of crime is an establishment of a circle of circumstances to be proved in case; others associate this concept with the establishment by proving the time, place, method of committing a criminal act, the person who committed it, and other circumstances relating to the crime; some lawyers believe that the crime was solved with the establishment and exposing the criminal and bringing him to justice; there is also an opinion that the crime can be considered fully disclosed with the entry of the court verdict into force or after the decision to terminate the criminal case is made. 
There are other points of view. Such a spread of opinions about the essence of the concept of "crime detection" indicates that this category is not sufficiently developed theoretically.

R.S. Belkin expressed the most complete and comprehensive opinion on this issue in his textbook "Course of criminology". In his opinion there are the following positions:

1. "Crime detection" - is the concept of operational search means the offender has been found. Everything else rather characterizes the stage of crime's investigation but not its detection, because it has already been solved (the offender has been found).

2. "Crime detection" - is the establishment of data about the crime and the perpetrator of its commission in such a volume that allows to bring charges. The moment of detection is linked to the moment when the charge is ordered.

3. "Crime detection" - is the establishment of all proof subject's circumstances, which are the basis for completing the preliminary investigation and drawing up an indictment.

4. "Crime detection" - is the entire process of proceeding in a case that ends with a court sentence's entry into force: a crime is disclosed for when the case verdict has entered into legal force (Belkin, 2001: 275).

The opinion of A.Yu. Shumilov deserves attention. In his comments to the federal law

On operative-search activities" he defines "crime detection" as "the activities authorized by the law of the subject (operative, etc.), aimed at obtaining data that may lead a reasonable operational version about commission of a specific crime by a specific person, after excluding all other versions will be checked and rejected" (Shumilov, 2003: 18).

As noted earlier, scientists in law have different approaches to the "crime detection" definition especially if they represent different sciences (operational investigative activities, criminology, criminal law, criminal procedure). Therefore, it is difficult to formulate a general concept for all lawyers comparing their approaches.

Thus, if make direct sense of part 1 of article 49 of the Constitution (The Constitution of the Russian Federation adopted by popular vote December 12.1993), which guarantees that "everyone charged with a criminal offence will be presumed innocent until his guilt is proved as provided by federal law and established by a legally effective court decision", we can conclude completeness "crime detection" the sentence comes into legal force. 
Ivan Alexandrovich Zavyalov, Taulan Osmanovich Boziev, Nikolay Nikolaevich Bukharov, Alexandr Vladimirovich Shakhmatov y Nikolay Kazimirovich Pcholovsky

604

The concept of crime detection in Russian law

Solving crimes, which consists in identifying the person who committed the crime, in detaining him, processing, and proving his guilt, as well as in ensuring the trial of a criminal case until the court's verdict enters into force are most fully reflect law enforcement agencies' activities (Tatunts and Ponamareva, 2021).

However, this approach is not fully applicable for practical divisions of internal affairs bodies' activities. Thus, in practice and when the accused person took an active part when applying the criminal law rules that we announced earlier and related to the mitigation of punishment or release from punishment, we would have to wait for the sentence to enter into force in a criminal case. The terms of criminal proceedings must be reasonable (Article 6.1 of the "Criminal Procedure Code of the Russian Federation" (December 18, 2001)), which clearly will not be facilitated by waiting for the entry of the sentence into legal force.

In addition, this interpretation of the "crime detection" will not allow to quickly and accurately compile and analyze statistics in practice. Such statistics is necessary for rapid action to counter a specific type of crime in a particular area or the Russian federation subject, will not allow the territorial bodies' heads of internal affairs to identify problem areas and respond quickly respond to them.

\section{Conclusion}

We offer to leave the term "Crime detection" in theory of law, because, as we have shown earlier, it mostly complies sense and spirit of Part 1 of Article 49 of the Constitution. For practitioners of law enforcement, it would be better to use the phrase "establishment and detention of person (s) who committed the crime". By the way this phrase already applies in mentioned the Interdepartmental order "On Unified Accounting of Crimes" (General Prosecutors office of Russia, the Ministry of Internal Affairs of Russia, the Ministry of Emergency Situations of Russia, the Ministry of Justice of Russia, the Federal Security Service of Russia, the Ministry of Economic Development of Russia, the Federal Drug Control Service of Russia, 2005).

We understand that such a proposal would entail the need for changes in such basic normative legal acts in the field of combating crime, such as penal code, criminal procedure code and the law "On Operational Search Activities", but it must be done in order to avoid confusion and improve enforcement. 


\section{Bibliographic References}

ANYUSHINA, Marina; BESTAEVA, Elena; SUYAZOV, Viacheslav; SHIRYAEVA, Svetlana; SHUTIKOVA, Nataliya. 2021 "National Security: Theoretical-Legal Research” In: Cuestiones Políticas, Vol. 39, No. 69, pp. 317-325.

BELKIN, Rafail Samuilovich. 2001. Course of criminology: Textbook for universities. Yunity. Moscow, Russia.

CRIMINALCODEOFTHE RUSSIAN FEDERATIONNo.63-FZ.1996. Available online. In: https://rg.ru/2007/11/12/ukrf-dok.html Consultation date: 27/01/2019.

CRIMINAL PROCEDURE CODE OF THE RUSSIAN FEDERATION No. 174FZ. 2001. Available online. In: https://rg.ru/2001/12/22/upk-dok.html Consultation date: 27/01/2019.

FEDERAL LAW No. 144-FZ. 1995. "On operational search activities" (amended on July 6, 2016). Available online. In: https://rg.ru/1995/o8/18/rozysksite-dok.html. Consultation date: 27/01/2019.

FEDERAL LAW No. 3-FZ. 2011. "On police". Available online. In: https:// rg.ru/2011/02/07/police-dok.html Consultation date: 27/01/2019.

INTERDEPARTMENTAL ORDER No. 39/1070/1021/253/780/353/399. 2005. "On Unified Accounting of Crimes" (as amended on February 20, 2014). Rossiiskaia Gazeta. Available online. https://rg.ru/2006/01/25/ uchet-prestupleniy-dok.html. Consultation date: 27/01/2019.

IVANOV, Dmitriy Aleksandrovich; FADEEV, Pavel Vladimirovich; ALIMAMEDOV, Elmir Nizamievich; DUNG, Vo Kim. 2020a. "Provision of the rights and legitimate interests of legal entities that have been victims of crimes" In: Revista Turismo Estudos \& Práticas. Vol. S5, pp. $1-7$.

IVANOV, Dmitriy Aleksandrovich; TOKAREVA, Ekaterina Viktorovna; SHEPELEVA, Olga Rinatovna; CHASOVNIKOVA, Olga Georgievna; STATSYUK, Denis N. 2020b. "Compensation for damage caused by a crime in pre-trial proceedings in criminal cases: issues of theory and practice" In: Revista Inclusiones. Vol. 7, No. S4-7, pp. 255-263.

ORDER OF THE MINISTRY OF INTERNAL AFFAIRS OF RUSSIA, No. 356. 2018. "About the position statement about appointment and payment of police remuneration for assistance in solving crimes and apprehending persons who have committed them". Available online. In: https:// 
Ivan Alexandrovich Zavyalov, Taulan Osmanovich Boziev, Nikolay Nikolaevich Bukharov, Alexandr Vladimirovich Shakhmatov y Nikolay Kazimirovich Pcholovsky

606

The concept of crime detection in Russian law

rg.ru/2018/08/22/mvd-prikaz-356-site-dok.html Consultation date: 27/01/2019.

OZHEGOV, Sergey Ivanovich. 1981. Dictionary of the Russian language: about 57,000 words. Russian language. Moscow, Russia.

PUSHKAREV, Viktor Victorovich; GAEVOY, Alexasnder; SKACHKO, Anna Vladilenovna; KOLCHURIN, Andrei; LOZOVSKY, Denis. 2019. "Criminal prosecution and qualification of cybercrime in the digital economy: In: JOURNAL OF ADVANCED RESEARCH IN DYNAMICAL AND CONTROL SYSTEMS. Vol. 11, No. 8, pp. 2563-2566.

SHUMILOV,AlexanderYu. 2003.CommentontheFederal Law"On Operational Search Activities". With an article-by-article application of regulations and documents. 5 th edition, revised and expanded. Publishing house of Shumilova I.I. Moscow, Russia.

TATUNTS, Svetlana Akhundovna; PONAMAREVA, Anastasia Mikhailovna. 2021. "Post-Soviet Russian Identity Building and Politics of Memory: Scientific and Public Discourse" In: Cuestiones Políticas. Vol. 39, No. 69, pp. 407-423.

THE CONSTITUTION OF THE RUSSIAN FEDERATION. 1993. Rossiiskaia Gazeta. Available online. https://rg.ru/2009/01/21/konstitucia-dok. html. Consultation date: 27/01/2019.

THI LAN HONG, Nguyen; VAN TUYEN, Tran; PUSHKAREV, Viktor Victorovich; FADEEV, Pavel Vladimirovich; KHMELEV, Sergey Alexandrovich. 2020. "Criminal prosecution of persons who do not speak the language of criminal process" In: Revista Inclusiones. Vol. 7, No. S3-3, pp. 121-125. 


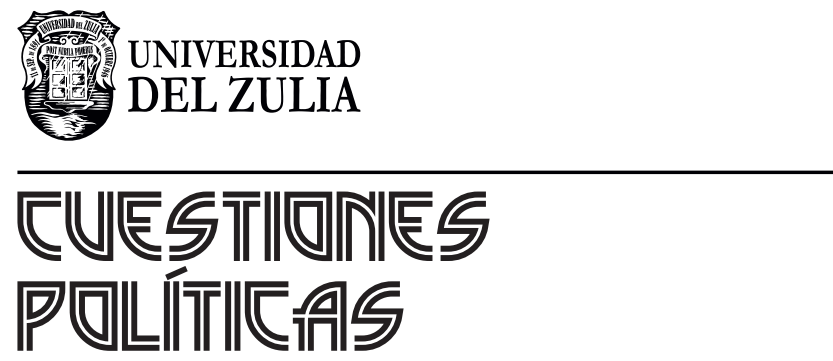

Vol.39 No Especial

Esta revista fue editada en formato digital y publicada en octubre de 2021, por el Fondo Editorial Serbiluz, Universidad del Zulia. Maracaibo-Venezuela 